\title{
STRUCTURAL CHANGE IN EXPORTS AND ECONOMIC GROWTH: COINTEGRATION AND CAUSALITY ANALYSIS FOR SPAIN (1961-2000)
}

\author{
Jacint Balaguer and Manuel Cantavella-Jordá*
}

\section{WP-EC 2002-22}

Correspondence to: J. Balaguer. Universitat Jaume I. Department of Economics, Campus Riu Sec. 12071 Castellón (Spain). Tel.: 34-964-728612 / Fax: 34-964-728591 / E-mail: coll@eco.uji.es.

Editor: Instituto Valenciano de Investigaciones Económicas, S.A.

Primera Edición Septiembre 2002

Depósito Legal: V-3614-2002

IVIE working papers offer in advance the results of economic research under way in order to encourage a discussion process before sending them to scientific journals for their final publication.

\footnotetext{
* Unitat Pre-Departamental d'Economia, Universitat Jaume I.
} 


\title{
STRUCTURAL CHANGE IN EXPORTS AND ECONOMIC GROWTH: \\ COINTEGRATION AND CAUSALITY ANALYSIS FOR SPAIN (1961-2000)
}

\author{
Jacint Balaguer and Manuel Cantavella-Jordá
}

\begin{abstract}
A B S T R A C T
In this paper the Spanish export-led growth hypothesis is re-examined from the trade liberalisation process initiated four decades ago. For this purpose it is taken under consideration both the export expansion and the progression from "traditional" exports to manufactured and semi-manufactured exports. A new evidence is reported for the above period. Alongside a feedback between aggregate exports and real output, it has been proved that the structural transformation in export composition has also become a key factor for Spain's economic development.
\end{abstract}

Keywords: structural change in exports, economic growth, causality

\section{R E S U M E N}

En este trabajo se estudia el sector exportador como motor del crecimiento económico español a partir del proceso de liberalización comercial iniciado hace cuatro décadas. Para este propósito se ha tenido en cuenta tanto la expansión de las exportaciones agregadas como el cambio en la estructura de las mismas. Los resultados indican que existe doble causalidad entre la expansión de las exportaciones y el crecimiento de la producción real y que, además, la transformación experimentada en la estructura exportadora hacia los sectores tecnológicos y manufactureros ha sido un factor clave en el desarrollo económico español de los últimos años.

Palabras clave: estructura exportadora, crecimiento económico, causalidad 


\section{INTRODUCTION}

A distinctive feature of the Spanish economy has been the rapid and sustained growth of their exports during the last four decades. This phenomenon contrasts with the evolution of exports in the precedent period in which the economy was characterised by a protectionism and autarky situation. The process of growth in exports had its origin in an outward-looking regime known as the Stabilisation and Liberalisation Plan of 1959. Since then, Spain has carried out a continued process of liberalising its economy finally leading to the integration of the country in the European Union in $1986{ }^{1}$

The effects of a new open trade regime and a policy of promoting exports on domestic real output was the fundamental concern dealt with in Balaguer and Cantavella-Jordá (2001). A comparison between the autarky period and the trade liberalisation period through the use of historical series for the last century was carried out. In contrast with the existing evidence for the preceding period, the aggregate export evolution was a significant factor in order to explain economic growth in the last four decades. After highlighting the importance of export expansion in that period, it would be interesting now to re-examine that cycle taking into consideration some additional factors. Thus, bearing in mind that a great part of historical time series were estimated, ${ }^{2}$ new data series will be used now and, what it is more important, information about the change in export composition will be analysed.

\footnotetext{
1 A very important change of strategy came about in Spanish trade policy with the Stabilisation and Liberalisation Plan of 1959. This policy was characterised for the liberalisation of imports leading to the acquisition of the necessary capital goods for the economy's productive expansion. Moreover, it was established the golden parity of peseta at the International Monetary Fund and at the same time the decision of a devaluation from 42 pesetas per dollar to 60 pesetas per dollar was taken. Although the implementation of the plan was an important starting point, the exports takeoff should be placed between 1967 and beginning of 70s. Three more factors influenced the initial boost: first, a new devaluation of domestic currency; second, a great expansion of international trade and third, the gradual improvement and adaptation of export promoting programmes. The establishment of the former Export Promoting Institute in 1982 (currently, External Trade Institute) reflects a continued willingness of applying a policy of increasing exports. When Spain joined the European Union in 1986 its trade policy moved froma cooperation scenario to an integrated status with the rest of the member countries.

2 In that previous paper, most real output and real export time series data are based on estimations carried out by Carreras (1989) and Tena (1989) respectively. The shorter span of the present paper allows us to directly resort to output in real terms and specific price indices for Spanish exports which can be collected from the International Financial Statistics. Probably, these price indices will enable us to deflate nominal exports in a more precise way.
} 
A time perspective provided by the last forty years underlines the fact that the new industrial sectors have succeeded in external markets. ${ }^{3}$ In general, Spain has gone from a residual exports model, based on the country's agricultural surplus, to a trade model focused on an outward-oriented demand of manufactured and semi-manufactured products.

Specifically, as it can be seen in Table 1, exports of agricultural goods (mainly citrus products, wine, vegetable oils and legumes) have gone from representing half of country's exports to a little more than the tenth part of total exports. The gradual lost in the relative weight of these "traditional" products reflects a significant transformation of the productive specialisation towards semi-manufactured goods, capital goods and consumption goods (especially durable goods). ${ }^{4}$

Table 1. Sectoral structure of exports (percentages)

\begin{tabular}{lccccc}
\hline \multicolumn{1}{c}{ Year } & $\mathbf{1 9 6 1}$ & $\mathbf{1 9 7 0}$ & $\mathbf{1 9 8 0}$ & $\mathbf{1 9 9 0}$ & $\mathbf{2 0 0 0}$ \\
\hline Agricultural goods & 53.76 & 34.85 & 17.86 & 11.61 & 11.42 \\
Energy products & 5.91 & 5.49 & 3.95 & 4.84 & 3.62 \\
Consumption goods & 11.91 & 21.38 & 25.54 & 25.84 & 28.05 \\
Semi-manufactures and & 28.42 & 38.28 & 52.65 & 57.71 & 56.91 \\
capital goods & & & & & \\
\hline
\end{tabular}

Source: Own calculations from Boletín Estadístico del Banco de España

The basic hypothesis about export-led growth suggests that the expansion of aggregate exports have a favorable impact on economic growth. Two are the fundamental reasons. First, the Keynesian approach, which indicates that injections into the circular flow of income caused by the aggregate exports, implies an improvement in the output level via the multiplier effect. Secondly, the level of exports increases foreign

\footnotetext{
3 Moreno (1997) deals with the determinants of Spanish exports for different industrial sectors. His paper shows evidence about the fact that general technological and advertising effort, have a significant effect on the evolution of exports of each one of sectors in the 1978-1989 period.

4 In the beginning of the period, the scarce production of cars was oriented to the domestic market, nevertheless, during the last decade, the car exports represented almost $60 \%$ of total consumption exports (agricultural products are not included).
} 
exchange receipts, which, in turn, allow stimulating the imports of essential inputs in the production system. Both approaches would justify the fact that aggregate exports have been widely used in order to analyze the external demand effect on economic development. $^{5}$

Nevertheless, the use of this information may be insufficient when, as in the most recent Spanish period, the export expansion is combined with the existence of a deep change in export structure. In fact, independently of the expansion of export sectors associated with traditional goods, and therefore the expansion in aggregate exports, the structural change in export composition has also been frequently suggested as a fundamental parameter of a country's economic growth. As Feder (1983) argues, allocation of productive resources to the external demand-oriented sectors is a very important factor in order to remove allocative inefficiencies and, therefore, increase the output level. More efficiency in external demand-oriented sectors may be originated by the response to greater competition in international markets, by new technologies that are available from foreign rivals, and by greater economies of scale because industries are no longer constrained by the domestic economy. ${ }^{6}$ This could particularly be remarkable during the first stages of the economy's liberalisation until the maximum allocative efficiency has been achieved. Nevertheless, very few empirical studies have addressed the dynamics of sectoral exports despite its importance in explaining economic growth. ${ }^{7}$

In this paper then, the Spanish export-led growth hypothesis is re-examined for the last four decades. For this purpose, not only exports and economic growth as such are taken under consideration but also the structural change in exports. The empirical approach used in this analysis allows, in a simple way, to study the export growth effect caused by the distribution of resources from the traditional exports to manufactured exports. To our knowledge, there are not empirical papers that capture, in an explicit form, the economic effects of this transition.

\footnotetext{
5 The link between exports and economic growth has been the subject of considerable research in the last two decades. An excellent review about those studies can be seen in Shan and Sun (1998).

${ }^{6}$ See Romer (1986).

${ }^{7}$ For example, Ghatak, et al. (1997) and Amin Gutiérrez de Piñeres and Ferrandino (1997).
} 


\section{DATA, METHODOLOGY AND EMPIRICAL RESULTS}

The empirical analysis uses annual data and the sample period spans from 1961 to 2000. This paper considers three variables in logarithmic terms: real domestic output $(Y)$, real aggregate exports $(E X)$, and a variable of export composition in relative terms $(E C)$. The $E C$ variable has been constructed by including exports of consumption goods, semi-manufactures and capital goods (stockbreeding and agricultural products, and fuel are excluded) divided all by total exports. It will try to capture the structural transformation from "traditional" exports to "non-traditional" exports.

Both the export composition by sectors and total exports used in this paper have been gathered from Boletín Estadístico del Banco de España. Aggregate exports have been deflated by a specific price index referred to export prices. These two variables plus the real gross domestic product have been collected from the International Financial Statistics (International Monetary Fund).

In order to undertake the export-led growth analysis it is important to first examine the time series properties of the variables involved in the model. A univariate examination will show us whether output, exports and export structural change are stationary or not. If they are stationary, that is, if they do not drift above its long-run growth path, then, one could apply standard ordinary least squares and evaluate the outcomes derived from simultaneous regressions. If they are non-stationary, then, one should carry out a cointegration analysis to see if at least those variables are tied up together in the long run and therefore the residuals stemming from the corresponding regressions are stationary. The final step would require the construction of an error correction model where the dynamics, including the long-run information, is incorporated. The direction about the impact of each of the variables can be determined from that analysis.

The stationarity of the series was investigated by employing the unit root tests developed by Dickey and Fuller (1979, 1981), and Phillips and Perron (1988). The joint use of both tests tries to overcome the common criticism that unit root tests have limited power in finite samples to reject the null hypothesis of non-stationarity. Table 2 reports the augmented Dickey-Fuller and Phillips Perron test statistics for the log levels and fist differences of the logs of real output, real exports and structural change in export composition respectively. According to the results shown in Table 2, the null hypothesis that the levels of the series contain a unit root can not be rejected independently of the 
model specification. Unit root tests re-run on first-differenced data reject the null, that is, in first difference form they are $\mathrm{I}(0)$ and in level form the series are $\mathrm{I}(1)$ (Engle and Granger, 1987).

Table 2. Augmented Dickey-Fuller and Phillips Perron Unit Root Tests (levels and first differences)

\begin{tabular}{lcccccc}
\hline Variables & $\tau_{\tau(\mathbf{A D F})}$ & $\tau_{\mu(\mathbf{A D F})}$ & $\tau_{(\mathbf{A D F})}$ & $\tau_{\tau(\mathbf{P P})}$ & $\tau_{\mu(\mathbf{P P})}$ & $\tau_{(\mathbf{P P})}$ \\
\hline$L Y$ & & & & & & \\
$L E X$ & $-1.47(0)$ & $-1.79(1)$ & $-0.29(0)$ & $-1.62(1)$ & $-1.83(1)$ & $-0.73(1)$ \\
$L E C$ & $-1.17(1)$ & $-1.08(2)$ & $1.73(2)$ & $-0.77(1)$ & $-1.82(1)$ & $0.93(1)$ \\
$\Delta L Y$ & $-2.32(0)$ & $-2.19(1)$ & $-1.80(1)$ & $-1.29(2)$ & $-2.27(2)$ & $-1.12(2)$ \\
$\Delta L E X$ & $-3.75(2)$ & $-2.81(1)$ & $-2.55(2)$ & $-3.28(2)$ & $-3.73(2)$ & $-3.18(2)$ \\
$\Delta L E C$ & $-4.96(2)$ & $-3.90(1)$ & $-2.95(1)$ & $-4.63(1)$ & $-4.21(1)$ & $-3.49(1)$ \\
\hline Critical values & $-8.38(1)$ & $-4.93(1)$ & $-3.88(2)$ & $-8.26(2)$ & $-7.61(2)$ & $-6.47(2)$ \\
$(10 \%, 5 \%)$ & $-3.19 /$ & $-2.60 /$ & $-1.62 /$ & $-3.19 /$ & $-2.60 /$ & $-1.62 /$ \\
\hline
\end{tabular}

Notes: ADF stands for Augmented Dickey Fuller; PP for Phillips Perron; $\tau_{\tau}$ represents the most general model with a drift and trend; $\tau_{\mu}$ is the model with a drift and without trend; $\tau$ is the most restrictive model without a drift and without trend.

Numbers in brackets are number of lags used in the ADF test in order to remove serial correlation in the residuals. When using PP test, numbers in brackets represent the truncation lag parameter.

Symbol $\Delta$ represents the corresponding variable in first differences.

Tests for unit roots have been carried out on E-VIEWS 3.0.

The second step is to test for cointegration among those three variables using the Johansen's (1988) methodology. ${ }^{8}$ The lag length of the level vector autoregression system has been determined by minimising the Akaike (1969) Information Criterion (AIC). Table 3 reports the cointegration results. Both $\lambda M A X$ and Trace tests suggest that there is a single significant cointegrating vector. ${ }^{9}$ The existing relationship among real output, real exports and structural change in export composition exports for Spain is not spurious and they move together in the long run between 1961 and 2000. They are,

\footnotetext{
${ }^{8}$ Greenaway and Sapsford (1994) underline the endogenous nature of the export growth variable within an output growth equation since exports actually are themselves a component of output via the national income accounting identity. This is a problem that is fortunately overcome given that in the first place Johansen deals with all variables as potentially endogenous and secondly, again, all the variables of our model are treated symmetrically in the standard Granger causality test.

9 Trends in the variables and in the data generation process were allowed for in estimation, nevertheless, the results were not practically sensitive to estimation method.
} 
therefore, causally related, at least in one direction (Engle and Granger, 1987). In this case, then, it can be said that either unidirectional or bi-directional Granger causality must exist as far as stationary variables are incorporated in the model. Table 3, second panel, exhibits the normalised cointegrating vector. The long run parameters appear to be positive regarding output and their robustness can be checked in Table 4 where the three variables are significant and therefore enter the cointegration space.

Table 3. Johansen Maximum Likelihood Cointegration Tests (1961-2000)

\begin{tabular}{|c|c|c|c|c|}
\hline $\begin{array}{c}\text { r: number of } \\
\text { cointegrating vectors } \\
\text { (null hypothesis) }\end{array}$ & $\lambda \mathbf{M A X}$ & Trace & $\begin{array}{c}\text { Critical values } \\
95 \% \text { and } 90 \%(\lambda \mathrm{MAX})\end{array}$ & $\begin{array}{c}\text { Critical values } \\
95 \% \text { and } 90 \% \text { (Trace) }\end{array}$ \\
\hline $\mathrm{r}=0$ & $23.01 *$ & $33.26^{*}$ & $20.97 / 18.60$ & $19.96 / 17.85$ \\
\hline $\mathrm{r} \leq 1$ & 7.23 & 10.25 & $14.86 / 12.07$ & $9.24 / 7.52$ \\
\hline$r \leq 2$ & 3.01 & 3.01 & $3.76 / 2.68$ & $3.76 / 2.68$ \\
\hline \multicolumn{5}{|c|}{ Parameter Estimates (normalised) } \\
\hline \multicolumn{3}{|c|}{ Variables } & \multicolumn{2}{|c|}{ Cointegrating vector } \\
\hline \multicolumn{2}{|c|}{$L Y$} & & \multicolumn{2}{|c|}{-1} \\
\hline \multicolumn{2}{|c|}{$\operatorname{LEX}(+)$} & & \multicolumn{2}{|c|}{0.12} \\
\hline \multicolumn{2}{|c|}{$\operatorname{LEC}(+)$} & & \multicolumn{2}{|c|}{2.01} \\
\hline
\end{tabular}

Notes: $\lambda \mathrm{MAX}$ and Trace are the likelihood ratio statistics for the number of cointegrating vectors. Estimation has been performed with MICROFIT 3.0.

* Indicates significance at 5 percent level, critical values are based on Osterwald-Lenum (1992).

In the second panel, $L Y$ denotes domestic income, $L E X$, exports, and $L E C$, export composition (all variables in natural logarithms). In brackets are the expected signs for $L E X$ and $L E C$. Parameter estimates express different elasticities.

Table 4. Tests of Parameter Restrictions on $L Y, L E X$ and $L E C\left(0=\alpha_{0} L Y+\alpha_{1} L E X+\alpha 2 E C\right)$

\begin{tabular}{cc}
\hline Parameter restriction & $\begin{array}{l}\text { Chi-squared } \\
\text { test statistic }\end{array}$ \\
\hline$\alpha_{0}=0$ & 13.27 \\
$\alpha_{1}=0$ & 12.63 \\
$\alpha_{2}=0$ & 11.86 \\
\hline
\end{tabular}

Note: The critical value with one degree of freedom at 5 per cent significance level is 3.84 . 
The third and final step, then, should involve a causality test based on the results provided by the long-run regression. The standard Granger causality test is applied. The structure of this equation is the following:

$$
\begin{aligned}
& D L Y=\alpha_{0}+\sum_{i=1}^{n} \beta_{i} D L Y_{t-i}+\sum_{j=1}^{n} \gamma_{j} D L E X_{t-j}+\sum_{k=1}^{n} \delta_{k} D L E C_{t-k}+\theta R E S_{t-1}+\varepsilon_{t} \\
& D L E X=\phi_{0}+\sum_{i=1}^{m} \eta_{i} D L E X_{t-i}+\sum_{j=1}^{m} \varpi_{j} D L Y_{t-j}+\sum_{k=1}^{n} \varphi_{k} D L E C_{t-k}+\sigma R E S_{t-1}+\mu_{t}(2) \\
& D L E C=\chi_{0}+\sum_{i=1}^{n} \varsigma_{i} D L E C_{t-i}+\sum_{j=1}^{n} \psi_{j} D L E X_{t-j}+\sum_{k=1}^{n} \tau_{k} D L Y_{t-k}+v R E S_{t-1}+\pi_{t}
\end{aligned}
$$

where $\varepsilon_{t}, \mu_{t}$ and $\pi_{t}$ are uncorrelated disturbances. In order to make valid inferences on causality all these variables must be stationary. Thus, the first differences of the three variables (DLY, DLEX and DLEC) and the residuals (RES) obtained from the cointegrating vector are included in the Granger causality test structure. The model characterised by equations (1), (2) and (3) focuses on the short-run dynamics among real output, real exports, and structural change in export composition combining at the same time the long-run information which is contained in the residuals. Again, since the results derived from these tests may be sensitive to the selection of the lag length, the AIC has been used and one lag has been finally selected.

The results of Granger causality tests are presented in Table 5. Focusing first on the real output equation (1), the growth of real exports ( $L E X)$ appears to "Grangercause" the growth of real output $(L Y)$ at $5 \%$ significance level. The inclusion of past information on the export variable improves the forecast for output. Nevertheless, it is found at the same time that real exports are driven by economic growth, that is, a bidirectional causality exists between exports and output. Another attractive outcome is that the export structural transformation ( $L E C)$ seems to cause exports $(L E X)$. This result is compatible with the fact that the resource movement from one sector to another has aimed at satisfying the external demand of goods with greater added value. Finally, the null of no causality from the structural change in export composition ( $L E C$ ) towards economic expansion $(L Y)$ is rejected. This result shows evidence regarding the importance of that variable in the explanation of the export-led growth process. 
Table 5. Granger causality tests

\begin{tabular}{lcc}
\hline Null hypothesis & F-Statistic & Probability \\
\hline$L E X$ does not Granger cause $L Y$ & 4.24 & 0.047 \\
$L Y$ does not Granger cause $L E X$ & 9.29 & 0.004 \\
$L E C$ does not Granger cause $L Y$ & 7.30 & 0.010 \\
$L Y$ does not Granger cause $L E C$ & 2.00 & 0.165 \\
$L E C$ does not Granger cause $L E X$ & 5.62 & 0.023 \\
$L E X$ does not Granger cause $L E C$ & 0.28 & 0.596 \\
\hline
\end{tabular}

Note: Tests for causality have been carried out on E-VIEWS 3.0.

An additional long-run causality test was carried on by applying the error correction model for each of the variables (Table 6). ${ }^{10}$ All the diagnostic tests plus basic statistics confirm the adequacy of those models (second panel of Table 6). Nevertheless, it should be noted that the Estatistics are not employed for the interpretation of the corresponding error terms and therefore the coefficient of the second model would not be significant. Thus, the existence of Granger causality for the long term is given from the exports and composition of the latter with respect to real output (equation 1) although the adjustment is slow (-0.04) and from exports and growth towards export composition (equation 3) where the path to the long-run equilibrium is fast $(-0.49)$. Short-term impacts coming from exports and export composition towards economic growth are positive and lower than those in the long-run. Growth has, at the same time, a positive influence on exports and export composition in the short run.

${ }^{10}$ No structural changes were found during the sample period according to different stability tests. 
Table 6. Error correction model

\begin{tabular}{|c|c|c|c|c|c|}
\hline $\begin{array}{c}\text { Variables } \\
\Delta L Y \text { (dependent } \\
\text { variable) }\end{array}$ & $\begin{array}{c}\text { Coefficients } \\
\left(t^{\prime} s\right)\end{array}$ & $\begin{array}{c}\text { Variables } \\
\Delta L E X \\
\text { (dependent } \\
\text { variable) }\end{array}$ & $\begin{array}{c}\text { Coefficients } \\
\left(t^{\prime} s\right)\end{array}$ & $\begin{array}{c}\text { Variables } \\
\Delta L E C \\
\text { (dependent } \\
\text { variable) }\end{array}$ & $\begin{array}{c}\text { Coefficients } \\
\text { (t's) }\end{array}$ \\
\hline$C$ & $\begin{array}{c}0.89 \\
(3.97)\end{array}$ & $C$ & $\begin{array}{l}-26.56 \\
(-2.67)\end{array}$ & $C$ & $\begin{array}{l}-17.02 \\
(-4.79)\end{array}$ \\
\hline$\triangle L E X$ & $\begin{array}{c}0.03 \\
(2.04)\end{array}$ & $\Delta L Y$ & $\begin{array}{c}0.07 \\
(1.62)\end{array}$ & $\Delta L Y$ & $\begin{array}{c}0.03 \\
(1.95)\end{array}$ \\
\hline$\triangle L E C$ & $\begin{array}{c}0.09 \\
(1.97)\end{array}$ & $\triangle L E C$ & $\begin{array}{c}-0.89 \\
(-2.24)\end{array}$ & $\Delta L E X$ & $\begin{array}{c}-0.11 \\
(-1.83)\end{array}$ \\
\hline$R E S_{-1}$ & $\begin{array}{c}-0.04 \\
(-3.96) \\
\end{array}$ & $R E S_{-1}$ & $\begin{array}{c}-0.23 \\
(-2.68) \\
\end{array}$ & $R E S_{-1}$ & $\begin{array}{c}-0.49 \\
(-4.80) \\
\end{array}$ \\
\hline $\mathrm{R}^{2}$ & 0.61 & & 0.31 & & 0.46 \\
\hline Adjusted $\mathrm{R}^{2}$ & 0.56 & & 0.24 & & 0.37 \\
\hline Standard error & 0.01 & & 0.09 & & 0.03 \\
\hline $\mathrm{F}$ & 12.48 & & 3.26 & & 5.28 \\
\hline Serial correlation & $(0.754)$ & & $(0.577)$ & & $(0.115)$ \\
\hline Functional form & $(0.209)$ & & $(0.898)$ & & $(0.056)$ \\
\hline Normality & $(0.656)$ & & $(0.694)$ & & $(0.844)$ \\
\hline Heteroscedasticity & $(0.824)$ & & $(0.642)$ & & $(0.741)$ \\
\hline
\end{tabular}
rejected.

Note: The numbers between parentheses are the percentages at which the null hypothesis is

\section{CONCLUDING REMARKS}

This paper focuses on the role of exports as engine of Spanish growth in the last four decades but with the particularity of taking under consideration the existence of a deep structural change in exports. The weight of primary goods in international trade in the beginning of the sixties has declined in favour of manufactured and semimanufactured products. The motivation of this paper aims at examining whether the economic growth has been spurred by a general increase of exports or maybe by the resource allocation coming from less efficient export sectors to those more efficient or maybe by both of them.

In the first place, it was obtained evidence about the existence of a long-run relationship among output, aggregate export expansion, and export structural change. The results indicate that exports are a determinant factor for Spain's real output. 
Moreover, economic growth also reinforces export expansion There exists, then, a reverse causality between those two variables.

Another interesting outcome is that the change in the productive specialisation stemming from the absorption of external markets turns out to be, along with export expansion, a key factor for the Spanish economic development. This phenomenon indicates that the resource allocation towards most industrialised export sectors has been important for its economy. These two results are also confirmed for the long run.

Therefore, it can be said that, even in circumstances in which the evolution of exports is kept constant, it is possible that the resource allocation towards more competitive sectors generated by external dynamics may cause significant growth rates. In this sense, not only the export promoting policy has a fundamental role in the economic growth, but also it has to be supported by a suitable industrial policy that favours the mobility of resources towards the efficient export sectors. 


\section{REFERENCES}

Akaike, H. (1969) Fitting autoregressive models for prediction, Annals of the Institute of Statistical Mathematics, 21, 243-47.

Amin Gutiérrez de Piñeres, S. and M. Ferrantino (1997) Export diversification and stuctural dynamics in the grwoth process: The case of Chile, Journal of Development Economics, 52, 375-91.

Balaguer, J. and Cantavella-Jordá, M. (2001) Examining the export-led growth hypothesis for Spain in the last century, Applied Economics Letters, 8, 681-85.

Carreras, A. (1989) La renta y la riqueza, in Estadísticas Históricas de España, siglos XIX-XX, Fundación Banco exterior, Madrid, 533-88.

Dickey, D. A. and Fuller, W. A. (1979) Distribution of the estimators for autorregressive time series with a unit root, Journal of the American Statistical Association, 74, 427-31.

Dickey, D. A. and Fuller, W. A. (1981) Likelihood ratio statistics for autoregressive time series with a unit root, Econometrica, 49, 1057-72.

Engle, R. F. and Granger, C. W. J. (1987) Cointegration and error correction: representation, estimation, and testing, Econometrica, 2, 251-76.

Feder, G. (1983) On exports and economic growth, Journal of Development Economics, 12, 5973.

Ghatak, S., Milner, C., and Utkulu, U. (1997) Exports, export composition and growth: cointegration and causality evidence for Malasya, Applied Economics, 29, 21323

Greenaway, D. and Sapsford, D. (1994) What does liberalisation do for exports and growth? Weltwirschaftliches Archives, 130, 152-74.

Johansen, S. (1988) Statistical analysis of cointegration vectors, Journal of Economic Dynamics and Control, 12, 231-54.

Moreno, L. (1997) The determinants of Spanish industrial exports to the European Union, Applied Economics, 29, 723-32.

Osterwald-Lenum, M. (1992) A note with quantiles of the asymptotic distribution of the maximum likelihood cointegration rank test statistics, Oxford Bulletin of Economics and Statistics, 54, 461-72.

Phillips, P. and Perron, P. (1988) Testing for a unit root in time series regression, Biometrica, 75, 333-46. 
Romer, P. M. (1986) Increasing returns and long run growth, Journal of Political Economy, 94, 1002-37.

Shan, J. and Sun F. (1998) On the export-led growth hypothesis: the econometric evidence from China, Applied Economics, 30, 1055-65

Tena, A. (1989) Comercio Exterior, in Estadísticas Históricas de España, Siglos XIX-XX. Madrid, Fundación Banco Exterior, 329-61. 